\title{
INNOVATIVE STRUCTURED FISH MEAT PRODUCTS FROM BALTIC SPRAT (SPRATTUS SPRATTUS BALTICUS)
}

\author{
Sandra Muizniece-Brasava ${ }^{1 *}$, Asnate Kirse-Ozolina ${ }^{1}$, Ilze Gramatina ${ }^{1}$, Inga Ciprovica ${ }^{1}$, Andrey Gorbatovskiy ${ }^{2}$, \\ Sanita Sazonova ${ }^{1}$, Evita Straumite ${ }^{1}$, Zanda Kruma ${ }^{1}$, Martins Sabovics ${ }^{1}$, Daiga Kunkulberga ${ }^{1}$, Janina Kivite ${ }^{1}$, \\ Tatjana Kince ${ }^{1}$, Jelena Zagorska ${ }^{1}$ \\ ${ }^{I}$ Department of Food Technology, Faculty of Food Technology, Latvia University of Life Sciences and Technologies, Rigas iela 22, \\ Jelgava, Latvia,e-mail: sandra.muizniece@llu.lv \\ ${ }^{2}$ Department of Production of Raw Materials and Products of Animal Breeding, Faculty of Technologies, Belgorod State Agricultural \\ University named after V. Gorin, ul. Vavilova 1, Mayskiy 308503, Belgorod region, Russia
}

\begin{abstract}
Fish is very important in the diet, providing complete protein, unsaturated $\omega 3$ fatty acids, calcium, phosphorus and vitamin D. However, Baltic sprat (Sprattus sprattus balticus), one of the most abundant fish stocks in the Baltic Sea, is underutilised due to its small size. The aim of the study was to develop structured fish forcemeat using whole fish from the Baltic Sea small Clupeiformes fish for further use in finished and semi-finished fish products. The testing of fish as raw material and developed structured fish forcemeat showed that all parts of fish can be used in the production as valuable ingredients. Due to the textural properties of the structured fish forcemeat, the possibilities of using it in finished and semi-finished fish products is wide. A total of seven basic product groups - sausages, terrines, frozen semi-finished products, fish meatballs and other culinary preparations, dumplings, pies, pasta and ravioli - were developed. Products made from structured fish forcemeat have a high nutritional value, particularly with regards to protein content and amino acid profile.
\end{abstract}

Keywords: structured fish forcemeat, semi-finished products, nutritional value, processing

\section{Introduction}

Fish is an important source of complete protein, unsaturated fatty acids, minerals $(\mathrm{Ca}, \mathrm{P})$ and vitamins (A, D) in the diet (Tilami, Sampels, 2017). One of the main catch in the Baltic sea is Baltic sprat (Sprattus sprattus balticus) (Ministry of Agriculture (2017), often underutilised due to its small size. Such minerals as calcium and phosphorus are concentrated in fish cartilage, scales, tail and bones (Stanek et al., 2013), thus suggesting the use of whole fish for production of high value products.

As shown by Proskina et al. (2018), the catch quotas available to Latvia (set by Council Regulation (EU) $2016 / 1903)$ were decreased for cod $(-57 \%)$, Baltic herring $(-1 \%)$ and salmon $(-10 \%)$, while a significant increase of $20 \%$ was given to sprats in 2017 . Economic consideration is one of the main reasons why the replacement of structured cod mincemeat with structured forcemeat from small Clupeiformes fish caught in the Baltic sea should be studied (Proskina et al., 2018).

The replacement of structured white fish mincemeat with small clupeid fish would also allow to reduce the production of traditional canned sprats, export of which have decreased by almost $25 \%$ due to Russian import ban on EU products (Russian embargo..., 2019).

The aim of the study was to develop structured fish forcemeat using whole fish from the Baltic Sea small Clupeiformes fish for further use in finished and semifinished fish products.

\section{Materials and Methods}

Raw materials

Baltic sprat (Sprattus sprattus balticus) in two thermal conditions was provided by Piejura Ltd. for the preliminary research: chilled fish 12 hours after catch and frozen fish in a flash freezer.

\section{Experimental design}

The laboratories of Faculty of Food Technology, Latvia University of Life Sciences and Technologies were used for raw material testing and innovative product development and quality analyses.

The preliminary research was carried out to determine: a) the possibilities to use whole fish for the development of new products and b) the effect of freezing on fish quality. A total of three fish samples and two thermal conditions were tested: chilled and frozen whole sprats, headed and gutted sprats, and sprat heads. The main part of the research was to develop structured fish forcemeat recipe and test the possibilities for its applications in new product development.

\section{Development of structured fish forcemeat}

When developing structured fish forcemeat from whole fish, two opposite tasks must be completed. Firstly, fish must be homogenised to the level where fish structure is not completely destroyed and consumer can notice fish taste and texture, however, in this case, it is possible that fish bones and other undesirable fish parts are present. Secondly, with a more intense homogenisation, a fine, highly homogeneous and paste-like texture is obtained, which becomes less viscous (overly fluid) due to the destruction of the muscles. To solve this problem, the addition of textured soy is suggested to substitute the lost texture from the intense homogenisation.

The main operations of structured fish forcemeat production are given in Figure 1.

For structured fish forcemeat production fresh, chilled or frozen fish can be used. When using frozen fish, there is no thawing, but frozen fish blocks are chopped in cylindrical or guillotine industrial blades. This allows to 
reduce cutter-mixer blade load and speed up homogenisation. It also ensures a low temperature in the coarse-ground fish mincemeat, which has a positive effect on the colour and safety of the product.

Emulsification in a high-speed cutter-mixer is performed until a rough consistency is obtained.

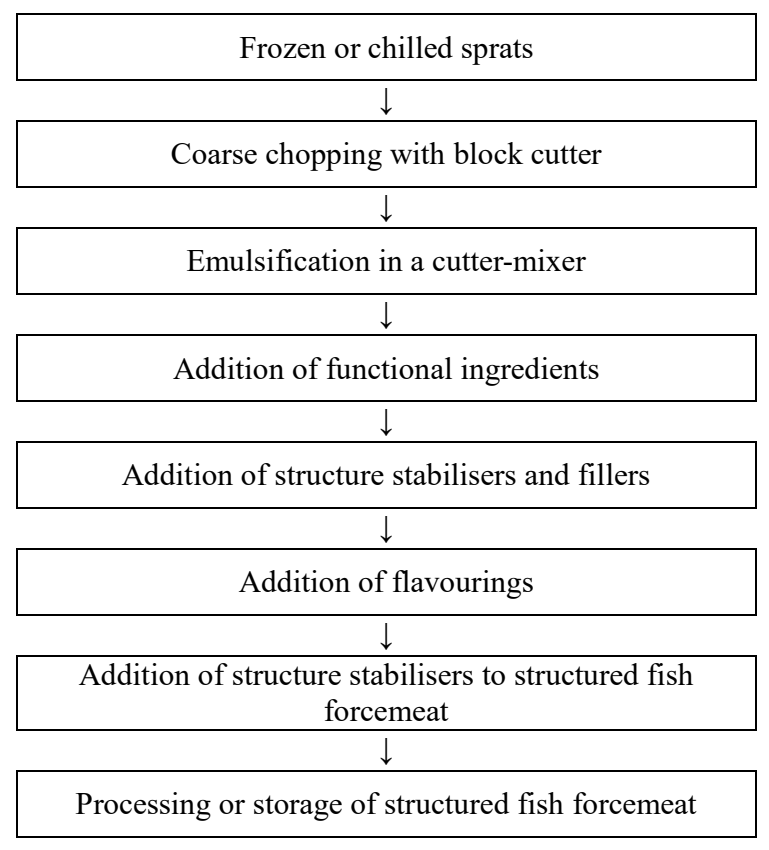

\section{Figure 1. General process scheme of structured fish forcemeat production}

Such functional ingredients as food-grade sodium phosphate (E339), salt and titanium dioxide (E171) are added. Titanium dioxide works as the colourant (EFSA, 2016) and should be added before other ingredients. Fish is crushed whole without heading and gutting, and fillet rinsing, therefore, such preservatives as microorganism inhibitors (e.g. potassium sorbate) can be used (Bashir et al., 2017).

Structure stabilizers and fillers of plant origin allow to stabilise low viscous consistency of emulsified fish forcemeat from sprats. According to the recipe, starch is added initially, followed by textured flour or semolina, then necessary consistency of the product is achieved by the addition of pea flour and food fibre.

Dried, fried or fresh onions are used as flavour additives. Before use, dried onions should be hydrated with water in a ratio $1: 2$.

Coarse texture of sprat structured forcemeat is given by the addition of hydrated textured soy.

Structured fish forcemeat is then forwarded to production of new products or stored up to $24 \mathrm{~h}$ at 2-6 ${ }^{\circ} \mathrm{C}$ temperature.

Development of semi-finished products from structured fish forcemeat

The production technology and recipes of co-extruded fish meatballs with filling already implemented at the factory was adapted to substitute traditional fish minced meat (which is more expensive) with structured fish forcemeat. As shown by Silovs and Dmitrijeva (2018), co-extrusion allows to obtain product, which is a combination of fish with sauce - structured fish products with various fillings. Such parameters as nutritional and amino acid profile were assessed in semi-finished products from structured fish forcemeat.

\section{Quality analysis}

Standard methods were used to assess nutritional composition of samples: protein content (PB-116 ed. II of 30.06.2014), fat content (PN-A-86509:1994), ash content (PN-A-79011-8:1988), amino acids (PB-53/HPLC ed. II of 30.12.2008), dietary fibre (AOAC 991.43:1993), fatty acid profile (ISO 12966-4:2015), salt content (PB-318/FAAS, ed. I of 27.07.2015). Carbohydrates were calculated by difference (FAO, 2003). Energy value was calculated according to EU Regulation No 1169/2011.

\section{Data processing}

MS Excel $v 16$ software was used to process the obtained data; differences were considered significant at $p<0.05$. All parameters were analysed in triplicate, mean values are given in tables. ANOVA and Tukey's test were applied to evaluate the results.

\section{Results and Discussion \\ Quality of chilled and frozen sprats}

The comparison of nutritional parameters of chilled and frozen sprats showed that there are not significant differences in protein, fat, ash content and energy value (Table 1). Literature studies show that there are several advantages of using frozen fish (Vanhaecke et al., 2010) if the production site is not close to water bodies: high microbiological quality, reduction of raw material costs, reduction of seasonal effect, increase in economic performance of production.

Table 1

Chemical composition of chilled and frozen sprat parts per $100 \mathrm{~g}$

\begin{tabular}{lcccc}
\hline \multirow{2}{*}{ Samples } & \multicolumn{4}{c}{ Composition parameters } \\
\cline { 2 - 5 } & Protein, g & Fat, g & Ash, g & Energy, kcal \\
\hline $\mathrm{AC}^{*}$ & $14.9^{\mathrm{a}}$ & $5.0^{\mathrm{a}}$ & $2.0^{\mathrm{b}}$ & $104.2^{\mathrm{a}}$ \\
$\mathrm{BC}$ & $16.0^{\mathrm{a}}$ & $5.1^{\mathrm{a}}$ & $1.7^{\mathrm{b}}$ & $110.3^{\mathrm{a}}$ \\
$\mathrm{DC}$ & $10.8^{\mathrm{b}}$ & $4.9^{\mathrm{a}}$ & $3.8^{\mathrm{a}}$ & $87.3^{\mathrm{b}}$ \\
$\mathrm{AF}$ & $15.0^{\mathrm{a}}$ & $4.8^{\mathrm{a}}$ & $2.2^{\mathrm{b}}$ & $103.2^{\mathrm{a}}$ \\
$\mathrm{BF}$ & $15.5^{\mathrm{a}}$ & $5.2^{\mathrm{a}}$ & $1.7^{\mathrm{b}}$ & $108.8^{\mathrm{a}}$ \\
$\mathrm{DF}$ & $10.3^{\mathrm{b}}$ & $4.7^{\mathrm{a}}$ & $3.6^{\mathrm{a}}$ & $83.5^{\mathrm{b}}$ \\
\hline
\end{tabular}

Values within the same column sharing the same letter are not significantly different $(\mathrm{p}>0.05)$.

* A - whole sprats, B - headed and gutted sprats, D - sprat heads, $\mathrm{C}-$ chilled, $\mathrm{F}-$ frozen.

In addition, testing of separate fish parts - whole sprats, headed and gutted sprats and sprat heads - established that sprat heads have a significantly higher content of ash $(\mathrm{p}<0.05)$ which represents total minerals. Fish heads make up $10-15 \%$ of the fish carcass (Smárason et al., 2014) and contains around $10 \mathrm{~g}$ of protein (Table 1), therefore showing potential as a raw 
material for structured fish forcemeat. Based on these results, whole sprats were used in the further experiments.

\section{Development of structured fish forcemeat}

Ground fish mincemeat is characterised by viscous consistency which must be stabilised with raw materials with good water binding properties. For this purpose, structural stabilizers (soy, carrot, wheat, beet, etc.), native starch (tapioca, potato, rice), textured flour (pea, rice, buckwheat, corn), semolina etc. can be used (Wild et al., 2014).

The flavour of the structured fish forcemeat depends on the percentage of fish in the finished product. By increasing the concentration of fish above $50 \%$, the organoleptic quality indicators - taste and colour decreased, whereas reduction of fish concentration to $40 \%$ improved the taste and colour. It is also possible to add various spices and herbs, onions (dried, fried, fresh) during structured fish forcemeat preparation, which greatly improves the taste of the finished product. The most effective additive that significantly improves the flavour of sprat structured forcemeat is onions and, with proper degree of shredding provides the product with a suitable texture. The final recipe of structured fish forcemeat from sprats is summarised in Table 2.

Table 2

Recipe of structured fish forcemeat

\begin{tabular}{lc}
\hline Ingredients & Amount, \% \\
\hline Frozen sprats & 45.45 \\
Wheat fibre & 3.64 \\
Water needed for wheat fibre & 7.27 \\
Titanium dioxide & 0.91 \\
Salt & 0.45 \\
Water-soluble food-grade sodium phosphate & 0.45 \\
Textured soy & 4.55 \\
Water needed for textured soy & 10.91 \\
Fresh onions & 5.45 \\
Semolina & 3.64 \\
Pea flour & 3.64 \\
Native rice starch & 2.73 \\
Water needed for fillers & 9.09 \\
Seasonings & 1.82 \\
\hline
\end{tabular}

Possibilities for structured fish forcemeat application in new product development

Due to the textural properties of structured fish forcemeat, its applications in food are wide. It can be used in at least seven product groups based on production specifics (Table 3, Figure 2). Sensory evaluation showed that new products from structured fish forcemeat were of good sensory quality and could compete with similar products (analogues from fillet minced meat) on the market (Straumite et al., 2018).

Quality comparison of raw sprats, structured fish forcemeat and semi-finished products

The comparison of nutritional and energy value of raw sprats, structured fish forcemeat and semi-finished breaded fish meat balls showed significant differences in several parameters (Table 4).

Table 3

Use of structured fish forcemeat in production of various products

\begin{tabular}{lc}
\hline Product group & Developed products \\
\hline $\begin{array}{l}\text { Sausages (emulsified fish } \\
\text { products) }\end{array}$ & $\begin{array}{c}\text { Cooked sausage } \\
\text { Frankfurters } \\
\text { Cooked bratwurst }\end{array}$ \\
$\begin{array}{l}\text { Pates (chilled fish culinary } \\
\text { products) }\end{array}$ & $\begin{array}{c}\text { Pâté } \\
\text { Terrine (classic, }\end{array}$ \\
Semi-finished products (frozen) & Dumplings \\
$\begin{array}{l}\text { Frozen and breaded / } \\
\text { battered fish culinary products }\end{array}$ & Fish fingers \\
& Fish meatballs \\
$\begin{array}{l}\text { Frozen culinary products } \\
\text { without breading }\end{array}$ & Curger patties \\
$\begin{array}{l}\text { Pies (baked pastry with } \\
\text { structured fish stuffing) }\end{array}$ & Cutlet in sauce \\
$\begin{array}{l}\text { Pasta (portion of pasta dough is } \\
\text { replaced with structured fish } \\
\text { forcemeat) }\end{array}$ & Meatballs \\
\hline
\end{tabular}

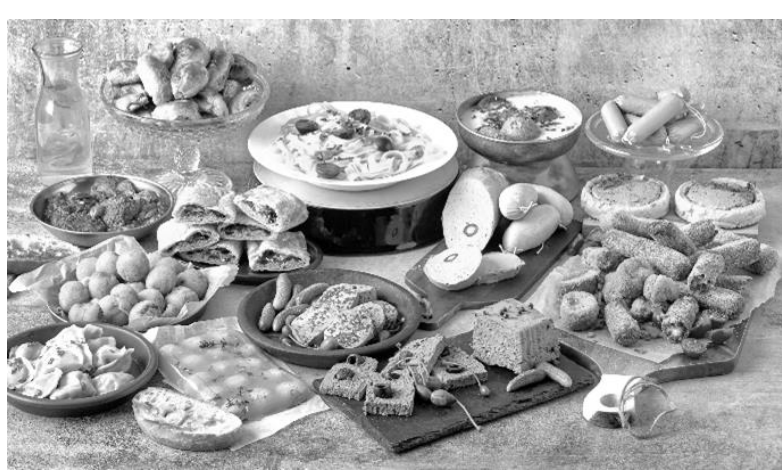

Figure 2. Products developed from structured fish forcemeat

Protein content in raw sprats, structured fish forcemeat and breaded fish meat balls is high, providing $30.8 \%$, $41.5 \%$ and $26 \%$ of energy value, respectively. All tested products are eligible for nutrient claim 'high protein' based on Regulation (EC) No 1924/2006.

All three samples also have a content of 'high omega-3 fatty acids' (Commission Regulation (EU) No 116/2010). The claim 'high omega-3 fatty acids' can be used when $100 \mathrm{~g}$ and $100 \mathrm{kcal}$ of products contain at least $80 \mathrm{mg}$ of the sum of long chain $\omega 3$ fatty acids eicosapentaenoic acid (EPA) and docosahexaenoic acid (DHA). Raw sprats contain $2100 \mathrm{mg}$ EPA and DHA per $100 \mathrm{~g}$ and $1220 \mathrm{mg}$ per $100 \mathrm{kcal}$, structured fish forcemeat - $1000 \mathrm{mg}$ per $100 \mathrm{~g}$ and $567 \mathrm{mg}$ per $100 \mathrm{kcal}$ and breaded fish meat balls - $800 \mathrm{mg}$ per $100 \mathrm{~g}$ and $329 \mathrm{mg}$ per $100 \mathrm{kcal}$.

In addition, structured fish forcemeat and semi-finished breaded fish meat balls have a 'high monounsaturated fat' content, providing over $46 \%$ of fatty acids from 
MUFA, and MUFA provides over 22\% of energy (Commission Regulation (EU) No 116/2010).

Table 4

Nutritional parameters and energy value of sprats and sprat products per $100 \mathrm{~g}$

\begin{tabular}{|c|c|c|c|}
\hline \multirow{2}{*}{ Parameters } & \multicolumn{3}{|c|}{ Samples } \\
\hline & RS* & SF & FMB \\
\hline Protein, $g$ & $13.20^{\mathrm{c}}$ & $18.30^{\mathrm{a}}$ & $15.80^{\mathrm{b}}$ \\
\hline Fat, $g$ & $12.10^{\mathrm{b}}$ & $9.40^{\mathrm{c}}$ & $14.00^{\mathrm{a}}$ \\
\hline Saturated (SAFA), g & $3.40^{\mathrm{a}}$ & $2.00^{\mathrm{b}}$ & $2.70^{\mathrm{ab}}$ \\
\hline Monounsaturated (MUFA), g & $4.40^{\mathrm{b}}$ & $4.40^{\mathrm{b}}$ & $7.30^{\mathrm{a}}$ \\
\hline Polyunsaturated (PUFA), g & $3.70^{\mathrm{a}}$ & $2.80^{\mathrm{b}}$ & $3.80^{\mathrm{a}}$ \\
\hline$-\omega 3, \mathrm{~g}$ & $3.20^{\mathrm{a}}$ & $1.80^{\mathrm{b}}$ & $1.80^{\mathrm{b}}$ \\
\hline - eicosapentaenoic acid, mg & $0.90^{\mathrm{a}}$ & $0.40^{\mathrm{b}}$ & $0.30^{\mathrm{b}}$ \\
\hline - docosahexaenoic acid, mg & $1.20^{\mathrm{a}}$ & $0.60^{\mathrm{b}}$ & $0.50^{\mathrm{b}}$ \\
\hline$-\omega 6, \mathrm{~g}$ & $0.50^{\mathrm{c}}$ & $1.00^{\mathrm{b}}$ & $2.00^{\mathrm{a}}$ \\
\hline$-\omega 9, \mathrm{~g}$ & $3.10^{\mathrm{b}}$ & $3.50^{\mathrm{b}}$ & $6.40^{\mathrm{a}}$ \\
\hline Trans fatty acids, $\mathrm{g}$ & $<0.10^{\mathrm{a}}$ & $<0.10^{\mathrm{a}}$ & $<0.10^{\mathrm{a}}$ \\
\hline Ash, g & $1.89^{\mathrm{b}}$ & $4.00^{\mathrm{a}}$ & $3.83^{\mathrm{a}}$ \\
\hline Carbohydrates, g & $2.60^{\mathrm{b}}$ & $1.30^{\mathrm{c}}$ & $13.00^{\mathrm{a}}$ \\
\hline Dietary fibre, $g$ & $0.00^{\mathrm{b}}$ & $1.30^{\mathrm{a}}$ & $0.80^{\mathrm{a}}$ \\
\hline Salt, $\mathrm{g}$ & $0.12^{b}$ & $2.05^{\mathrm{a}}$ & $1.88^{\mathrm{a}}$ \\
\hline Energy value, kJ & $716^{\mathrm{c}}$ & $737^{b}$ & $1014^{\mathrm{a}}$ \\
\hline
\end{tabular}

Values within the same row sharing the same letter are not significantly different $(\mathrm{p}>0.05)$.

* RS - raw sprats, SF - structured fish forcemeat, FMB semi-finished breaded fish meat balls

The rest of the differences in nutritional parameters can be explained by the recipes of sprat products; higher content of protein in structured fish forcemeat is due to the addition of textured soy, while higher content of carbohydrates in breaded fish meat balls is due to the coating and filling of the product.

One of the important parameters to verify the quality of new products is amino acid profile, as additional ingredients and the coating and filling can reduce the qualitative and quantitative amino acid content.

Amino acid composition of raw sprats shows (Table 5) that the total amount of amino acids per gram of protein is $806.4 \mathrm{mg}$, and based on the essential amino acid profile sprat protein is complete. A study by Mohanty et al. (2014) reviewed the amino acid profile of 27 different food fish and their results on sprat amino acid content is comparable to our results.

The results of amino acid content in structured fish forcemeat and breaded fish meat balls in $\mathrm{mg}$ per $\mathrm{g}$ protein indicates (Table 5) that the total amount of amino acids in fish balls per 1 gram does not differ significantly from the content of amino acids in $1 \mathrm{~g}$ protein of structured forcemeat $(\mathrm{p}>0.05)$.

The added ingredients for optimum structured fish forcemeat production have a positive effect on the amino acid profile, and structured fish forcemeat protein retains its full value after these technological improvements. It can also be concluded that the coating and the filling of fish balls has an insignificant effect on total amino acid content, especially with regards to essential amino acids.

Table 5

Content of amino acids in sprats and sprat products, $\mathrm{mg} \mathrm{g}^{-1}$ protein

\begin{tabular}{|c|c|c|c|c|}
\hline \multirow{2}{*}{ Amino acids } & \multicolumn{3}{|c|}{ Samples } & \multirow{2}{*}{$\begin{array}{c}\text { MAAP } \\
(\mathrm{FAO}, 2013)\end{array}$} \\
\hline & RS* & SF & FMB & \\
\hline Ala & 58.3 & 51.4 & 48.1 & - $* *$ \\
\hline Arg & 47.0 & 68.3 & 63.3 & - \\
\hline Asp & 72.7 & 96.7 & 92.4 & - \\
\hline Glu & 129.5 & 177.0 & 188.6 & - \\
\hline Gly & 53.8 & 49.2 & 46.2 & - \\
\hline Cys & 5.6 & 12.6 & 10.8 & - \\
\hline Pro & 34.1 & 49.2 & 52.5 & - \\
\hline Ser & 30.3 & 45.9 & 44.3 & - \\
\hline Tyr & 26.5 & 35.0 & 30.4 & \multirow{2}{*}{38} \\
\hline $\mathrm{Phe}^{\mathrm{x}}$ & 38.6 & 45.9 & 43.7 & \\
\hline $\operatorname{His}^{\times}$ & 18.2 & 25.1 & 24.1 & 15 \\
\hline $\mathrm{Ile}^{\mathrm{x}}$ & 35.6 & 39.9 & 38.0 & 30 \\
\hline $\operatorname{Leu}^{\times}$ & 68.2 & 74.9 & 72.8 & 59 \\
\hline $\operatorname{Lys}^{\times}$ & 76.5 & 75.4 & 61.4 & 45 \\
\hline $\operatorname{Met}^{\times}$ & 28.0 & 20.8 & 19.6 & 16 \\
\hline $\operatorname{Thr}^{\times}$ & 34.1 & 38.8 & 37.3 & 23 \\
\hline $\operatorname{Trp}{ }^{\times}$ & n.d. & n.d. & n.d. & 6 \\
\hline $\mathrm{Val}^{\times}$ & 49.2 & 43.7 & 43.0 & 39 \\
\hline Total & 806.4 & 949.7 & 916.5 & - \\
\hline
\end{tabular}
semi-finished breaded fish meat balls, MAAP - maintenance amino acid pattern.

** Pattern not defined by FAO.

${ }^{\times}$Essential amino acids.

n.d. - no data

Based on the FAO recommendations for maintenance amino acid pattern, protein of structured fish forcemeat and breaded fish meat balls is also complete, indicating that processing and additional ingredients do not affect the protein quality of new products.

\section{Conclusions}

The results of the study show that is it possible to use whole sprats in structured sprat forcemeat production, however, it is suggested to use no more than up to $50 \%$ of sprats in total forcemeat composition. Structured sprat forcemeat can be labelled 'high protein', 'high omega-3 fatty acids' and 'high monounsaturated fat', in addition, products made from it could be eligible for these claims as well. Protein of sprats and structured forcemeat is complete based on essential amino acid profile. Semi-finished breaded fish meat balls made from structured sprat forcemeat have a high nutritional value, particularly with regards to protein content and amino acid profile.

\section{Acknowledgment}

This study was supported by European Maritime and Fisheries Fund (EMFF) project (EMFF) project 
"Production of structured fish forcemeat from Baltic sea fish and its use in fish products", project no. 16-00F01101-000005.

\section{References}

1. Bashir K.M.I, Kim J-S., An J.H., HakSohn J., Choi J.S. (2017) Natural food additives and preservatives for fishpaste products: A Review of the past, present, and future states of research. Journal of Food Quality, Vol. 2017, p. 1-32.

2. Commission Regulation (EU) No $116 / 2010$ of 9 February 2010 amending Regulation (EC) No 1924/2006 of the European Parliament and of the Council with regard to the list of nutrition claims (OJ L 37/16, 10.2.2010, p.16-18).

3. Council Regulation (EU) 2016/1903 of 28 October 2016 fixing for 2017 the fishing opportunities for certain fish stocks and groups of fish stocks applicable in the Baltic Sea and amending Regulation (EU) 2016/72 (OJ L 295, 29.10.2016, p. 1-10).

4. EFSA (2016) Food colours: titanium dioxide marks reevaluation milestone. [accessed on 27.02.2019.]. Available: https://www.efsa.europa.eu/en/press/news/160914

5. FAO (2013) Dietary protein quality evaluation in human nutrition: Report of an FAO Expert Consultation. FAO Food and Nutrition Paper No 92. Rome: Food and Agriculture Organization of The United Nations. 66 p.

6. Kirse A., Karklina D., Muizniece-Brasava S., Galoburda R. (2017) Influence of sous vide treatment and high pressure processing on nutritional value and overall acceptance of pulse spreads. Proceedings of the Latvian Academy of Sciences. Section B, Vol. 71, No. 6 (711), p. $474-480$.

7. Ministry of Agriculture (2017) Action Programme for the Development of Fisheries 2014-2020, version 2.2, p. 132. [accessed on 12.03.2019.]. Available: https://www.zm.gov.lv/public/files/CMS_Static_Page_Do $\mathrm{c} / 00 / 00 / 01 / 11 / 39 /$ fs-

01usersLinda.BirinaDesktopAAProgramme_2014LV14M FOP001_2_2_lv.pdf

8. Mohanty B., Mahanty A., Ganguly S., Sankar T.V., Chakraborty K., Rangasamy A., Paul B., Sarma D., Mathew S., Asha K.K., Behera B., Aftabuddin M., Debnath D., Vijayagopal P., Sridhar N., Akhtar M.S., Sahi N., Mitra T., Banerjee S., Paria P., Das D., Das P., Vijayan K.K., Laxmanan P.T., Sharma A.P. (2014) Amino acid compositions of 27 food fishes and their importance in clinical nutrition. Journal of Amino Acids, Vol. 2014, p. $1-7$.

9. Proskina L., Pilvere I., Nipers A., Silovs M. (2018) Characteristics of the fishing industry in Latvia. In: Proceedings of the 2018 International Conference "Economic Science for Rural Development", Jelgava, Latvia, p. 56-64.
10. Regulation (EC) No 1924/2006 of the European Parliament and of the Council of 20 December 2006 on nutrition and health claims made on foods (OJ L 404, 30.12.2006, p. 9)

11. Regulation (EU) No $1169 / 2011$ of the European Parliament and of the Council of 25 October 2011 on the provision of food information to consumers, amending Regulations (EC) No 1924/2006 and (EC) No 1925/2006 of the European Parliament and of the Council, and repealing Commission Directive 87/250/EEC, Council Directive 90/496/EEC, Commission Directive 1999/10/EC, Directive 2000/13/EC of the European Parliament and of the Council, Commission Directives 2002/67/EC and 2008/5/EC and Commission Regulation (EC) No 608/2004 (OJ L 304, 22.11.2011, p. 18-63)

12. Russian embargo badly hurts Latvian fish canners. [accessed on 12.03.2019.]. Available: https://iegvu.agribusinessintelligence.informa.com/CO22 4125/Russian-embargo-badly-hurts-Latvian-fish-canners

13. Silovs M., Dmitrijeva O. (2018) Fish processing industry modernization and co-extrusion method in fish product assortment diversification. In: Proceedings of the 2018 International Conference "Economic Science for Rural Development", Jelgava, Latvia, p. 305-311.

14. Smárason B. Ö., Viðarsson J.R., Pórðarson G., Magnúsdóttir L. (2014) Life Cycle Assessment on fresh Icelandic cod loins. Report summary: Skýrsla Matís Resources \& Products. [accessed on 12.03.2019.]. Available: http://www.matis.is/media/matis/utgafa/2414_AVS-LCA-greining_Lokaskyrsla.pdf

15. Stanek M., , Peter E., Janicki B. (2013) Content of the calcium and phosphorus in the meat of Prussian carp (Carassius auratus gibelio Bloch, 1783) from the Lake Gopło (Poland). Journal of Central European Agriculture, Vol. 14(1), p. 1-10.

16. Straumite E., Gorbatovskiy A., Sazonova S., Gramatina I., Muizniece-Brasava S., Kruma Z., Kirse A., Ciprovica I., Sabovics M. (2018) Sensory evaluation of structured fish mass products from Baltic sprat (Sprattus sprattus balticus Schneider). In: Abstract book of $12^{\text {th }}$ Baltic Conference on Food Science and Technology "Food R\&D in the Baltics and Beyond" FOODBALT 2018 Conference, Kaunas, Lithuania, p. 108.

17. Tilami S.K., Sampels S. (2017) Nutritional Value of Fish: Lipids, Proteins, Vitamins, and Minerals. Reviews in Fisheries Science \& Aquaculture, Vol. 26(2), p. 1-11.

18. Vanhaecke L., Verbeke W., De Brabanderac H.F. (2010) Glazing of frozen fish: Analytical and economic challenges. Analytica Chimica Acta, Vol. 672 (1-2), p. 40-44.

19. Wild F., Czerny M., Janssen A.M., Kole A.P.W., Zunabovic M., Domig K.J. (2014) The evolution of a plant-based alternative to meat. Agro FOOD Industry $\mathrm{Hi}$ Tech, Vol. 25(1), p. 45-49. 